\title{
姿勢制御電極による電解曲がり穴加工*
}

笹原弘 之*1, 長尾昇平*2, 茅野雅 久*3

\section{Electrochemical Curved Hole Machining with Electrode Posture Control System}

Hiroyuki SASAHARA*4, Shohei NAGAO and Masahisa CHINO

${ }^{* 4}$ Graduate School of Bio-Applications and Systems Engineering, Tokyo University of Agriculture and Technology, 2-24-16 Nakacho, Koganei-shi, Tokyo, 184-8588 Japan

Almost holes such as cooling channels of a mold or hydraulic equipments are machined by drilling process. It is desirable to establish a cooling channel located within a constant distance along a curved surface of a cavity or a core. However, the drilling process cannot make curved holes. Therefore a curved hole machining technique is required. Some kinds of curved holes machining process have been proposed, but they have not reached the practical level. The objective of this study is to develop a curved hole processing method using the electrochemical machining with an electrode posture control system. The posture of an electrode is controlled with a stepping motor and the wire. A simulation technique to predict the electrode position in a hole and the hole path was also developed. It was shown that the proposed system is able to make curved holes with the reasonable efficiency and accuracy.

Key Words : Curved Hole Machining, Electrode Posture Control System, Electrochemical Machining

\section{1. 緒言}

近年, 射出成形品の複雑形状化や高精度化に伴い, 成 型時の金型温度の制御が重要となっている. 一般的に 金型の泠却流路形は，成形される製品形状に沿って一 定の距離に設けることが望ましいとされ, 例えば図1(a) の黒塗り部のような形状の製品に対しては，冷却流路 の形状も曲がり穴であることが望ましい.しかし，現状 では，同図(b)のようにドリル加工による直線状の穴を 繋ぐといった方法で妥協しており，曲がり穴加工法の 開発が求められている.また, エンジン部品や油圧部品 の冷却液や油の流路の加工においても, 曲がり穴が要 求される場合がある.

これまでに，いくつかの曲がり穴加工法が提案され ている. 円弧状の電極を回転軸で円軌道上を送りなが ら電解加工する方法(1), ユニバーサルジョイントによ る屈曲機構により電極の向きを制御しながら放電加工 を行う方法(2), フレキシブルなチューブの先端に電極 を取り付け，絶縁力バーの角度を傾けて電解加工を行 う方法 ${ }^{(3)(4)}$ ，圧縮したコイルばねを主軸に固定し，接続 した複数のワイヤの送り量を制御することによりコイ ルばねを屈曲，伸長させて先端に取り付けた電極に曲

*. 原稿受付 2007 年 3 月 2 日.

*1 正員, 東京農工大学大学院共生科学技術研究院 (丞 184-8588 小金井市中町 2-24-16).

*2 東京農工大学大学院機械システム工学専攻[現：ブリヂスト ン(株)].

*3 正員, 東京農工大学工学部.

E-mail : sasahara@cc.tuat.ac.jp
線軌跡上を運動させながら放電加工を行うことにより 曲がり穴加工を行う方法(5)(6)などが提案されている.い ずれの研究も工夫を凝らし曲がり穴加工を行っている が，高い自由度で長い距離の曲がり穴を加工できるま でには至っていない.したがって, 金型の成形性能を高 めるような泠却流路を実用的に加工するまでには至つ ていないのが現状である.

そこで本研究では, ほとんどの金属の加工が可能で あり, 工具の消耗がない電解加工を適用して, より自由 度の高い曲がり穴を加工することを目的とする. 電解 加工の, 電源と送り機構があれば加工が可能であり, 装 置が比較的シンプルに構成することができるといった 特徴を活かし，フレキシブルなチューブ先端に取り付 けた電極に屈曲機構を設けて, ワイヤを介してステッ ピングモータにより電極の姿勢を制御をしながら, 曲 率が変化する曲がり穴を電解加工する手法を開発し

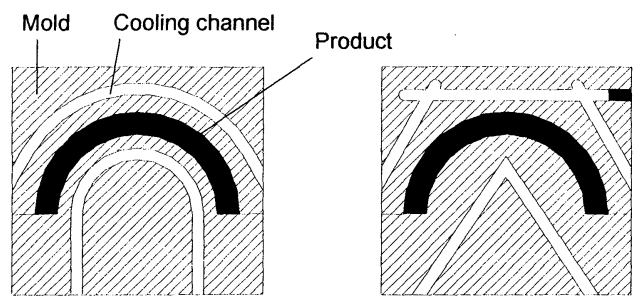

(a) Cooling channel consists (b) Cooling channel consists of curved holes of straight holes Fig.1 Cooling channel of a mold 
Table 1 Chemical composition and electro chemical equivalent of aluminum alloy A5052

\begin{tabular}{c|c|c|c|c|c|c|c|c}
\hline & $\mathrm{Si}$ & $\mathrm{Fe}$ & $\mathrm{Cu}$ & $\mathrm{Mn}$ & $\mathrm{Mg}$ & $\mathrm{Cr}$ & $\mathrm{Zn}$ & $\mathrm{Al}$ \\
\hline$W_{j(\%)}$ & 0.25 & 0.40 & 0.10 & 0.10 & $\begin{array}{c}2.20 \\
-2.80\end{array}$ & $\begin{array}{c}0.15 \\
-0.35\end{array}$ & 0.10 & Remain \\
\hline & & $1.04(+3)$ & $1.19(+2)$ & $0.51(+4)$ & & $0.65(+3)$ & & \\
$k_{j(\mathrm{~B} / \mathrm{Ah})}$ & - & $0.69(+2)$ & $2.37(+1)$ & $0.68(+3)$ & $0.45(+2)$ & $0.97(+2)$ & $1.22(+2)$ & $0.34(+3)$ \\
\hline
\end{tabular}

た.また，穴距離を延長した場合でも加工精度と穴経 路の自由度を高めるためには，加工位置の予測と制御 が重要となるが, 電極の姿勢制御状態と送り量とから 加工経路を予測する手法を提案し, 実際の加工経路と の比較を行ったので報告する。

\section{2. 電解加工の加工原理と加工速度}

2.1 電解加工による穴あけ加工の加工速度

電解加工において，溶解面積一定の場合の理論的 な加工速度 $v(\mathrm{~mm} / \mathrm{min})$ は，

$$
v=\eta \frac{k_{a}}{\rho} i
$$

と与えられる(7).ここで, $i$ は電流密度 $\left(\mathrm{A} / \mathrm{mm}^{2}\right), \rho$ は合 金の密度 $\left(\mathrm{g} / \mathrm{mm}^{3}\right), \eta$ は電流効率である.また， $K_{a}(\mathrm{~g} /$ $\mathrm{Ah})$ 恰金に含まれる成分の電気化学当量であり，合 金含有成分の電気化学当量とその含有割合から，

$$
\frac{1}{k_{a}}=\sum \frac{w_{j}}{k_{j}}
$$

と求められる．ここで， $w_{j}$ は合金に含まれる $j$ 番目の成 分元素の含有率, $k_{j}$ はその電気化学当量である.被加工 物として用いたアルミニウム合金A50520成分およ び，含まれる合金成分の電気化学当量を表1に示す.

実際の電解加工時には, 酸素の発生など金属溶出以 外の副反応が生じたり, 被加工金属が溶出だけでなく ある程度の大きさの塊となって脱落するなどの状況 が生じることがあり，電流効率 $\eta$ の值は変化すること になる．特に合金においては，加工条件に大きく左右 されることがあるため, 電流効率 $\eta$ の值を実験的に検 討した。

実験は加工速度の測定が容易となるように直線状 の穴加工とし, 電流密度, 電解液の流量, 電極先端の 形状の影響について調べた，図2に実験装置の概略を 示す. Z方向に移動可能なステージにパイプを介して 電極を取り付け，定電流電源により電流を供給する. 加工槽の電解液はポンプによりパイプを経て電極先 端部一供給される. 加工が進行して電極一被加工材間 の距離が広がると電圧が増加することを利用し, 加工 電圧が一定となるようZ軸ステージの位置を調整しな がら加工を進めた，そのとき，被加工材と電極との間

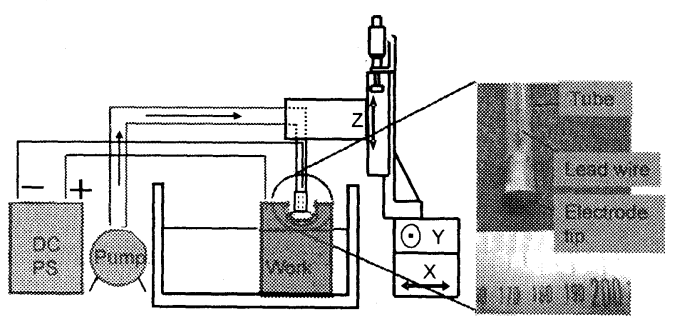

Fig.2 Schematic of the experimental set up for machining a straight hole

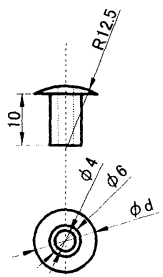

(a) Electrode $\mathrm{A}$

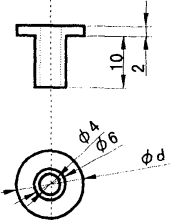

(b) Electrode B

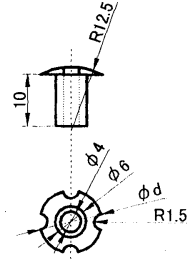

(c) Electrode $\mathrm{C}$
Table 2 Experimental conditions

\begin{tabular}{lc|cc}
\hline Work material & \multicolumn{2}{|c}{ A5052 } \\
\hline Electric current & $\mathrm{A}$ & \multicolumn{2}{|c}{10} \\
\hline Diameter of electrode d $\mathrm{mm}$ & \multicolumn{2}{|c}{13} \\
\hline Electric current density $\mathrm{A} / \mathrm{mm}^{2}$ & & \\
Electrode A & 0.09 & 0.18 & 0.35 \\
Electrode B & 0.10 & 0.19 & 0.36 \\
Electrode C & 0.11 & 0.23 & 0.43 \\
\hline Electrolyte & $20 \% \mathrm{NaCl}$ \\
\hline Electrolyte flow rate $\quad \mathrm{I} / \mathrm{min}$ & $1.0 \quad 5.4$ \\
\hline
\end{tabular}

隔は約0.3mmであった.

電極の形状は, 図3に示すような3タイプを製作し,下 記のような予想の下，形状による加工速度への影響を 調べた．いずれにおいても，電解液は電極中心の直径 $4 \mathrm{~mm}$ の穴から加工部へ供給され，電極外面およびパイ プの外側と穴壁の間を通って穴入口へと還流する。電 極Aは先端が球状であり，電極Bは先端を平坦として側 面との角部に電流を集中させて加工速度の増大を狙つ た.また,アルミ合金においては陽極面上に不導体化膜 が生成し，イオンの移動を制限することになるため効 率的にこれを除去することが必要であるが，電極Cで は電極周囲に電解液が流れやすいように外周に溝を設 けて加工速度の増大を狙った。

なお，電解液には $20 \% \mathrm{NaCl}$ 水溶液を用いた，表 $2 に$ 実 験条件をまとめて示す.

図4に実験によって得られた電流密度と加工速度と の関係を示す．全体として電流密度が増加するとそれ に応じて加工速度は向上することがわかる.また, 電解 液流量が大である同図(b)の方が，わずかではあるが加 


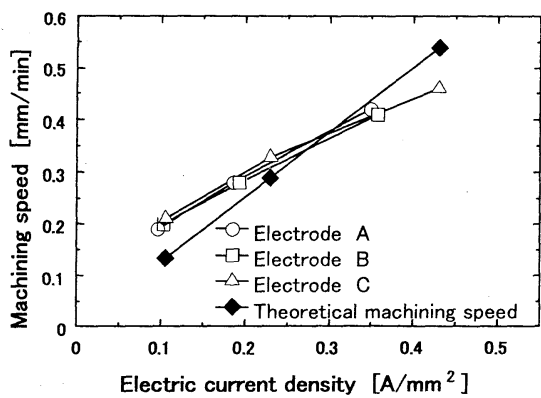

(a) Electrolyte flow rate $1.0 \mathrm{l} / \mathrm{min}$

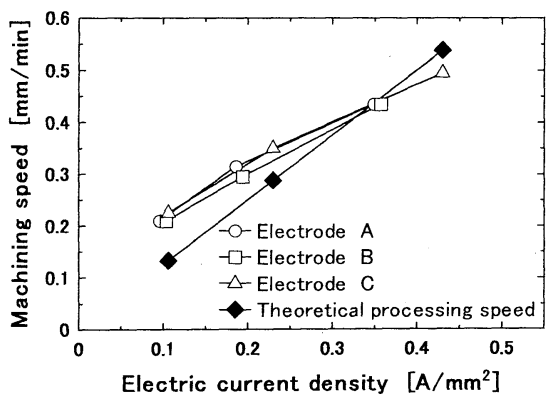

(b) Electrolyte flow rate $5.4 \mathrm{l} / \mathrm{min}$

Fig.4 Relationship between electric current density and machining speed

工速度は高かった. 一方, 電極の形状の違いによる加工 速度への影響はほとんど見られないことがわかる。

実験を行った電流密度 $0.09 \mathrm{~A} / \mathrm{mm}^{2} \sim 0.43 \mathrm{~A} / \mathrm{mm}^{2}$ 程度の 範囲では，加工速度はいずれの場合も電流密度にほぼ 比例しており, 加工速度 $v$ と電流密度 $i$ との間には, グラ フの傾きとして $v 0.83 i$ の関係が見られた.これは, 電 解加工される物質の量は電気量に比例するというファ ラデーの法則によるところが大きいと思われるが， A5052の電気化学当量から求められる加工速度の理論 值は $v=1.25 i$ であるのに対し, 実験值では電流密度が増 大寸るにつれて電流効率は低下する傾向が見られた。

一方で, 電流密度が $0.3 \mathrm{~A} / \mathrm{mm}^{2}$ 程度より小さい領域で は理論值よりも高い加工速度が実現されている. 電流 効率 $\eta$ を算出すると，電流密度が $0.09 \mathrm{~A} / \mathrm{mm}^{2}$ ，において は160\%から175\%程度に達している.これは, 被加工金 属が溶出だけでなくある程度の大きさの塊となって脱 落するなどの状況が生じているためだと考えられる が，目視で確認できるほどの粗大粒は観察されなかっ た. 一方, 電流密度が $0.3 \mathrm{~A} / \mathrm{mm}^{2}$ 程度より大きい領域で は，電流効率は100\%を下回っている. 電流効率が低下 する原因として, 陽極である被加工物表面からのガス の発生が考えられる. 電流密度が増大するにつれて電 気分解される水分子が増加し, 酸素の発生に消費され

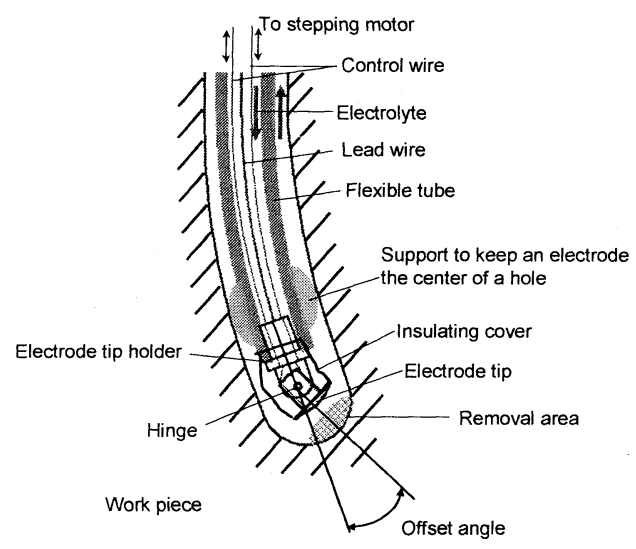

Fig.5 Schematic of curved hole machining

\section{るようになるためであると考えられる.}

\section{3. 電極の姿勢制御による曲がり穴加工}

本報では,フレキシブルなチューブ先端に取り付け た電極に屈曲機構を設け, ワイヤを介してステッピン グモータにより電極の姿勢を制御しながら，電極， チューブ，姿勢制御用ステッピングモータなどからな る加工ユニットを別途設置したステッピングモータ により送り駆動する実験装置を製作し，実際に曲がり 穴を加工した。

3.1 曲がり穴加工の加工原理 図5に提案する曲が り穴加工の概略を模式的に示す．電極はヒンジを介し て電極支持部に接続しており，電極支持部はフレキシ ブルチューブの先端に固定されている. 電極には チューブ内を通って2本のワイヤが接続されており, チューブの後端でプーリを介してステッピングモー タにより制御され，片方のワイヤが引かれれば他方が 同じだけ繰り出されるように動作し，ヒンジ周りに電 極を首振り運動させることができる.チューブの直径 は，電極の外径および加工される穴径よりも小さいた め, チューブの電極支持部付近が加工穴の中央に保持 されるようポリエチレン製のサポートを設置した. 電 解液の還流を妨げないよう，サポートは幅 $\times$ 長さ $\times$ 高 さが $1 \times 5 \times 1 \mathrm{~mm}$ の船底形状とし，チューブ外周の 3 力所 に $120^{\circ}$ 毎に等間隔で取り付けた.

曲がり穴が加工される原理として, 内山ら ${ }^{(3)}$ は「電極 方向に穴加工が進み，工具自らがその加工された穴に 倣っていく」と想定した．基本的にその考え方に則る が，加工中においても電極方向を自由に制御可能であ る点が内山らの手法とは異なる．これにより，例えば $\mathrm{S}$ 字形状や直線と曲線を組み合わせたような曲率が変 


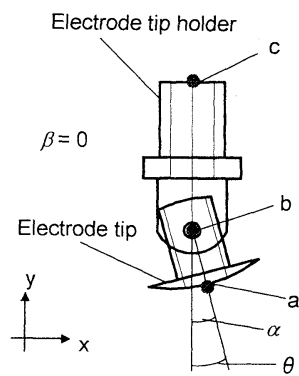

(a)

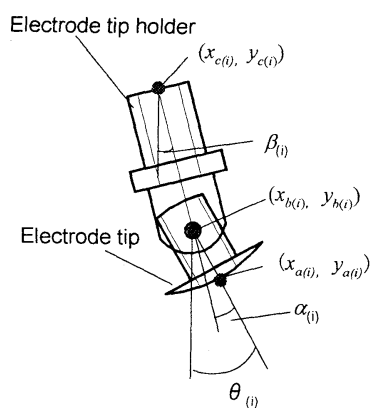

(b)
Fig.6 Posture of electrode in machining

化する穴経路も加工可能となる.また, 加工進行方向に 対して電極を回転させることによりスパイラル状など の三次元的な穴経路の加工も可能である.

また, 内山らが指摘しているように, 穴加工の進行に 伴い, 電極が穴内面に引っかかる現象が本研究におい ても見られたが，提案する電極姿勢の制御によりこれ が回避可能であることも後述する.

\section{2 曲がり穴の加工経路予測 金型の泠却流路な} どを加工する場合, 曲がり穴が深くなるほど, 加工位置 を予測・制御し, 設計通りの経路で加工することが必要 となる. 本報告では, 電極の姿勢制御状態と電極送り量 とから加工経路を予測する手法を提案する.

図6(a)に屈曲機構之電極を示寸. 点aは電極中央先端, 点bは電極の回転支点部, 点cは電極ホルダの後端であ り, 線分bcはフレキシブルチューブ端の中心軸と一致 する.ここでは, 加工進行方向に対する電極の回転を伴 う移動は考えず, 電極の首振りによる加工経路の予測・ 制御について考えることにする.

初期状態として線分 $\mathrm{bc}$ と平行に $y$ 軸をとり, 点 $\mathrm{a}, \mathrm{b}$, cの座標をそれぞれ $\left(x_{a}, y_{a}\right),\left(x_{b}, y_{b}\right),\left(x_{c}, y_{c}\right)$ とする. こ こで，電極ホルダに対する電極の傾きすなわちabと bc のなす角を $\alpha$ ，線分 $\mathrm{bc}$ の $y$ 軸に対する角度を $\beta$ とする. $\infty$ 同 值を制御しながら加工を行うことになる。

ここで，加工方向と電極の移動について以下のよう に仮定する. i) 電極先端において加工はbaの方向に進 み, 付随して点bは点aと同じ方向に進む. ii)それにより 加工された穴内壁を電極ホルダ部が倣うように進むの で, 点はは点aと同じ軌跡上を一定時間遅れて移動する.

これを微小ステップ每に繰り返すとき, $i$ ステップ時 点の状態を同図(b)k示寸. 各点の座標を $\left(x_{\alpha(1)}, y_{\alpha(i)}\right), \quad\left(x_{b}\right.$ $\left.(i), y_{b(i)}\right), \quad\left(x_{c(i)}, y_{(i)}\right)$ とすると電極ホルダである線分 $\mathrm{bc} の y$ 軸に対する角度 $\beta_{(i)}$ は

$$
\beta_{(i)}=\tan ^{-1} \frac{x_{b(i)}-x_{c(i)}}{y_{b(i)}-y_{c(i)}}
$$

となるので, 電極部の線分abのy軸に対する傾き $\theta_{(i)}$ は

$$
\theta_{(i)}=\alpha_{(i)}+\beta_{(i)}
$$

となる.電極およびチューブ全体は, ステッピングモー タにより送り駆動するが，ステッピングモータの 1 ス テップで電極が進む距離をlとすると，1ステップ後の 電極先端 (点a)の座標は,

$$
\begin{aligned}
& x_{a(i+1)}=x_{a(i)}+l \sin \left(\theta_{(i)}\right) \\
& y_{a(i+1)}=y_{a(i)}-l \cos \left(\theta_{(i)}\right)
\end{aligned}
$$

により表すことができる. 同様に点bの軌跡は,

$$
\begin{aligned}
& x_{b(i+1)}=x_{b(i)}+l \sin \left(\theta_{(i)}\right) \\
& y_{b(i+1)}=y_{b(i)}-l \cos \left(\theta_{(i)}\right)
\end{aligned}
$$

となる。

一方，点cは点 $\mathrm{a}$ と同じ軌跡上を遅れて移動するもの とするので, 点 $\mathrm{a}$ の各ステップ毎の座標值を記憶してお き, $(a b+b c) / l$ ステップ前の座標を点cの座標値とする. なお， その値が整数値でない場合は前後の座標値から 直線補間する.

以上の計算を繰り返すことにより電極の移動軌跡す なわち曲がり穴の加工経路を予測することができる.

3.3 加工穴径の予測次に, 加工される穴径の予測 について述べる. 提案する電解穴加工では, 電極佳より も大きな径の穴が加工される. 被加工物の電気化学当 量を $k_{a}(\mathrm{~g} / \mathrm{A} \cdot \mathrm{min})$, 比重を $\rho\left(\mathrm{g} / \mathrm{mm}^{3}\right)$, 加工時の電流をI $(\mathrm{A})$, 加工速度を $v(\mathrm{~mm} / \mathrm{min})$ とすると, 電解加工による1分間 あたりのワークの溶出量 $M_{a}(\mathrm{~g} / \mathrm{min})$ は

$$
M_{a}=k_{a} I
$$

となるから, 1分間あたり溶出体積 $V\left(\mathrm{~mm}^{3} / \mathrm{min}\right)$ は,

$$
V=\frac{M_{a}}{\rho}
$$

となる. これは, 単位時間に直径 $D(\mathrm{~mm})$ の穴が加工速度 $v(\mathrm{~mm} / \mathrm{min})$ で加工される体積 $\pi D^{2} v / 4$ 等しいので，加工 される穴径は,

$$
D=2 \sqrt{\frac{V}{\pi v}}=2 \sqrt{\frac{K_{a} I}{\rho \pi v}}
$$

により表すことができる.

以上により, 加工される曲がり穴の穴径と, 加工経路 が予測できる.

\section{4. 曲がり穴加工実験}

図7に実験装置の概略を示す.テーブル上に垂直にフ レームを設置し，フレームに取り付けられたスライド レール上を上下に加工ユニットが移動する. 加工二 ニットには電極姿勢制御用のステッピングモータ，フ 


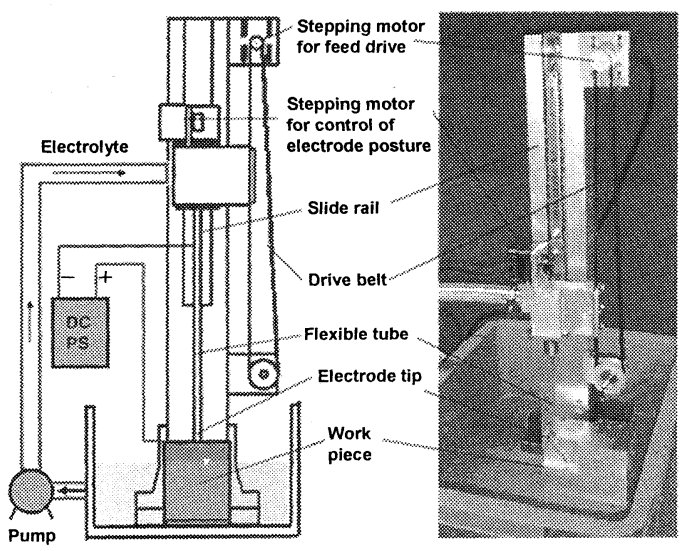

Fig.7 Schematic of the experimental setup

レキシブルチューブの一端が接続されており，チュー ブ内には直流電源のマイナスラインと電極姿勢制御用 の2本のワイヤが通っている. また電解液もこのパイプ を通して供給される. 加工ユニットはステッピング モータ, プーリを介してベルトにより駆動され, スライ ドレール上を上下に移動する.なお, 二つのステッピン グモータはモーションコントローラを搭載したPCに より制御する.

電極形状は図3(a)の球面状のものとし, 直径は9.1mm とした，定電流 $13.7 \mathrm{~A}$, 電解液流量 $5.4 \mathrm{l} / \mathrm{min}$, 電極送り速 度 $0.3 \mathrm{~mm} / \mathrm{min}$ として下の曲がり穴加工実験を行った. なお, 得られる曲がり穴の穴径は式 (9) を用いると, 約 $11 \mathrm{~mm}$ となる。

以下に例として3通りの加工を示す. 電極姿勢 (先端 の角度 $\alpha$ ) をスライドレール上の移動量すなわち加工 穴深さに対して図8に示すように制御した.いずれの場 合も, ワーク端面から $5 \mathrm{~mm} は \alpha=0^{\circ}$ で直線加工を行い,

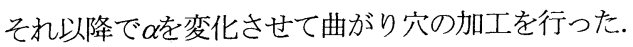

\section{$4.1 \alpha=9.5^{\circ}$ にステップ状変化を与えた場合 図9} に, 加工開始から $5 \mathrm{~mm}$ 直線穴加工し, 次いで $\alpha$ を $9.5^{\circ}$ 傾 けて深さ45mm程度まで加工を行った穴断面を示す.図 中の太実線は3章で示した予測方法により予測した経 路の中心である.曲がり穴は加工出来ているが, 予測し た加工経路との一致は良好ではない，深さ5mmの位置 で電極を $9.5^{\circ}$ 傾けたことにより, 被加工領域が急激に 曲線経路の内側に移動し，曲がり穴側面が段状となっ ていることがわかる．その部分と電極保持部とが干渉 し，電極の向きが予測とは異なったことがその主な原 因と考えられる。

$4.2 \alpha=13.3^{\circ}$ まで徐々に変化させた場合 そこ

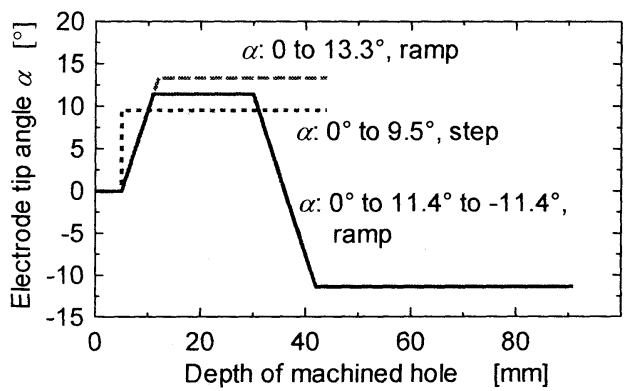

Fig. 8 Control sequence of electrode tip angle $\alpha$

で, 加工開始か $55 \mathrm{~mm}$ 直線穴加工した後, 急激な電極

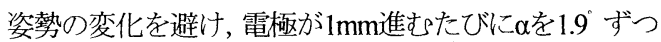
$13.3^{\circ}$ まで増加させ, 深さ45mm程度まで加工を行った 場合の結果を図 10 に示す. $\alpha=13.3^{\circ}$ と前述の9.5 の場合 より大きく傾けることにより，穴経路の全体的な曲率 半径は小さくなっているにもかかわらず，比較的良好 な形状の曲がり穴を加工することができている．電極 の姿勢変化を急激に行わない工夫をすることで電極 保持部と加工穴内壁との余分な干渉を回避し加工す ることができた．なお，穴径は11〜 12mm程度であり， 予測値 $11 \mathrm{~mm}$ よ大きくなる傾向があるが，段差が生 じることなく，ほぼ一定径の曲がり穴を加工できるこ とが示された.

予測した加工経路と比較すると, 戝9の場合よりは 良い一致が見られる. しかし, 実加工の経路の方が曲 率半径が大きくなっており, 最深部において $4 \mathrm{~mm}$ 程度 のずれを生じている.これは,今回提案した加工経路の 予測では，加工方向を電極先端の中心軸方向と仮定し たが, 実際の加工における電極先端の運動方向は, 電 極保持部の運動方向の影響を大きく受けるため, 想定 したよりも円弧状加工経路の外側の方で被加工面と 電極とのギャップが小さくなって加工速度は内側に 比べ高くなり，予測の加工経路よりも曲率半径が大き くなっていると考えられる.また，電解液の圧力によ る反力の作用や, チューブの復元力等の影響も加工経 路の曲率半径が予測よりも大きくなる原因の一部と 考えられる.

4.3 S字状の曲がり穴加工 図11に，加工開始から $5 \mathrm{~mm}$ 直線穴加工した後, 電極が $1 \mathrm{~mm}$ 進む毎に $\alpha$ を $1.9^{\circ}$ ず つ11.4まで増加させて深さ30mmまで加工し, 次いで

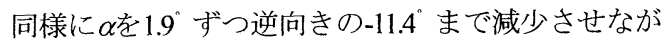
ら, 深さ $90 \mathrm{~mm}$ 程度まで加工を行った結果を示す. 加工 された曲がり穴の経路は, 電極姿勢の変化に対応して $\mathrm{S}$ 字状のものが実現できた. 


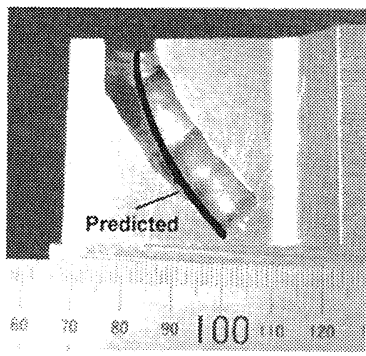

Fig.9 Predicted center line of machining path and machined curved hole

(Electrode angle $=9.5^{\circ}$ )

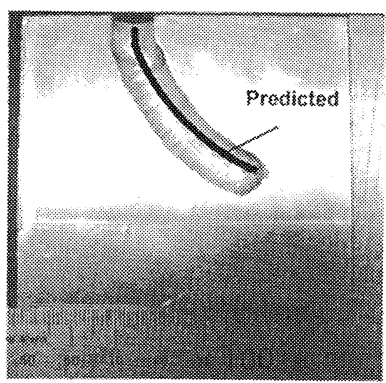

Fig.10 Predicted center line of machining path and machined curved hole

(Electrode angle was controlled from 0 to $13.3^{\circ}$ )

また, 前述の場合と同様に, 加工した曲がり穴経路は 予測した経路と完全には一致しなかったが，曲がり穴 の中心と加工経路の誤差は最大で約 $4 \mathrm{~mm}$ 程度であり, 第一次近似的な予測モデルであることを考慮すればか なり近い形状が得られていると言えよう.また, 加工時 間は5時間程度であったが, より大きな電流を供給する ことにより加工速度は高くすることが可能である.

\section{5. 結言}

本報告では, 屈曲機構を設けた電極の姿勢をワイヤ, ステッピングモータを用いて制御しながら電解加工を 行う曲がり穴加工法を提案し，以下の結果を得た。

(1) $0.09 \mathrm{~A} / \mathrm{mm}^{2} \sim 0.43 \mathrm{~A} / \mathrm{mm}^{2}$ の範囲の電流密度では, 加 工速度と電流密度にはほぼ比例関係が見られたが, 電流密度が増大するにつれて, 電流効率は低下し た．また，電解液の流量を増大させると，同程度の 電流密度であっても加工速度はわずかではあるが 高くなった。

(2) 屈曲機構付きの電極を, ワイヤ, ステッピング モータにより電極先端の姿勢を制御しする実験装 置を開発し，実際に穴径 $11 \mathrm{~mm}$, 深さ $90 \mathrm{~mm}$ 程度まで の曲がり穴を電解加工した. 電極の急激な姿勢変化 を避け徐々に行うことにより加工をすることで, 良

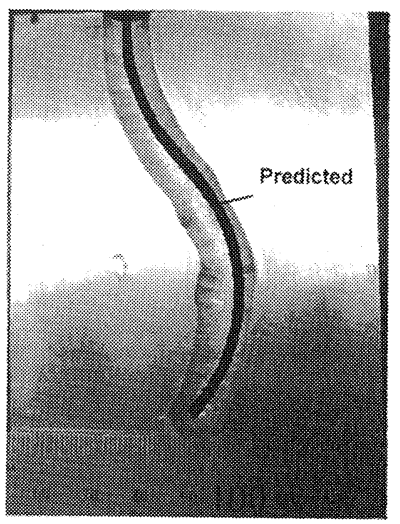

Fig.11 Predicted center line of machining path and machined curved hole

(Electrode angle was controlled from 0 to $11.4^{\circ}$ then to $\left.-11.4^{\circ}\right)$

好な形状の曲がり穴を加工することができた.

（3）屈曲機構付きの電極を用いた電解加工の加工経 路を予測する手法を提案し, 実加工した曲がり穴形 状と比較検討した. その結果, 実加工による加工経 路と比較的良好な一致が得られた. 誤差の発生要因 としては, 実加工での電極の進行方向は, 予測手法 で仮定した経路より曲線の外側になるためと考え られる。

\section{文献}

(1) Komai S., Komine S., Electrochemical machining of Curved Hole (in Japanese), Journal of The Japan Society of Electrical Machining Engineers, Vol.8, No.15 (1974), pp. $20-28$.

(2) Fukui M., Kinoshita N. , Developing a 'Mole' Electric Discharge Digging Machining, Annals CIRP, Vol. 38, No.1 (1989), pp.203-206.

(3) Uchiyama M., Shibazaki T., Development of Curved Hole Processing Technique Using Electrochemical Machining (1st Report) : Processing method by actuatorless tool, Journal of Japan Society for Precision Engineering, Vol.68, No.11 (2003), pp.1476-1480.

(4) Uchiyama M., Shibazaki T., Development of Curved Hole Processing Technique Using Electrochemical Machining (2nd Report) : Controllability of curvature of machined curved hole, Journal of Japan Society for Precision Engineering, Vol.69, No.10 (2003), pp.14921496.

(5) Ishida T., Takeuchi Y., Development of Electrode Feeding Drive Mechanism for Electrical Discharge Curved Hole Machining Using a Helical Compression Spring and Wires, Journal of Japan Society for Precision Engineering, Vol.65, No.7 (1999), pp.982-986.

(6) Miyake Y., Ishida T., Takeuchi Y., Electrical Discharge Machining of Constant Curvature Curved Hole by Means of Electrode Motion Control Device, Journal of Japan Society for Precision Engineering, Vol.71, No.11 (2005), pp.1388-1392.

(7) Ito H., Non-traditional Machining and Treatment, (in Japanese), (1970), Seibundoshinkosya. 